Vol.04, No.02, Oktober 2018

Doi: $10.24198 / \operatorname{cosmogov} . v 2 \mathrm{i} 2 . x x x x x$

\title{
MANAGING WASTEWATER IN DECENTRALIZED INDONESIA: COULD LOCAL DEMOCRACY IMPROVE PUBLIC SERVICE?
}

\author{
Diny Waskitawati ${ }^{1}$, Ida Widianingsih ${ }^{2}$, Budhi Gunawan ${ }^{3}$ \\ ${ }^{1}$ Post-Graduate Program Public Administration, Faculty of Social and Political S \\ Universitas Padjadjaran Bandung \\ ${ }^{2}$ Assoc. Prof in Public Administration Department, Faculty of Social and Po \\ Universitas Padjadjaran Bandung \\ ${ }^{3}$ Assoc. Prof in Anthropology Department, Faculty of Social and Polity
} Padjadjaran Bandung

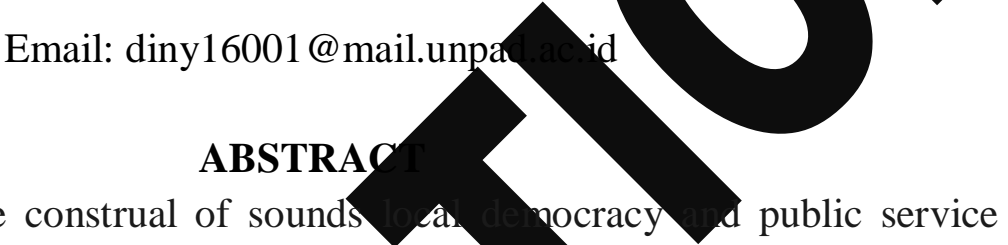

This article seeks the construal of sounds a a pocracy public service improvements in Indonesian decentralin conted bringing the example of wastewater management in Bandung andipality. Da dlected through series of interviews with respected ind uals in lved in wastewater service, particularly those who directlyengagd vater sanitation projects funded by local and external funding surive view on decentralization could create a more powerfu a rernmon in overseeing local development for more effective publin servi de the could be tested by the fragile administrative sys the ature local democracy. In the case of wastewater ser in hdung Junicipality, for example, the respected
institution can (Bandung Municipality Water Supply Agency) sh ess e nt un of fund compared to the same project funded by the Aus as one of Indonesian development partners. Sound gove noc an ministranive reform should be employed to achieve better py seryice per ince.

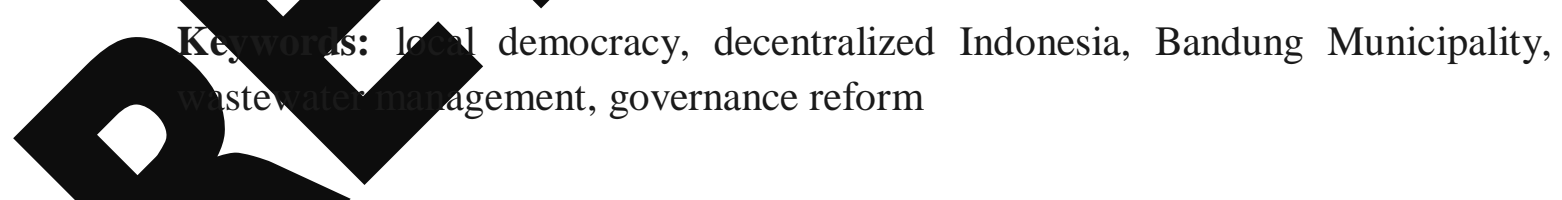

YTRODUCTION

More than ten years of the introduction of new Indonesian decentralization laws No. 22/1999 and $25 / 2009$, the transition towards a more democratic country remains challenging. Many argue that the "big bang" process of decentralization could contributes to the problematic implementation of the laws which led to two significants revisions of the decentralization laws (in 2004 and in 2008) (Erb, Priyambudi, \& Faucher, 
Vol.04, No.02, Oktober 2018

Doi: $10.24198 /$ cosmogov.v2i2.xxxxx

2005, p. 21; Widianingsih, 2006; Widianingsih \& Morrell, 2007; Widianingsih, 2015). Apart from continuous debates on the the PostSuharto decentralization laws, to some extend the laws give more power to local government in managing more effective and deliberative local development.

Decentralization tends to explore the process of local democratization and improve community participation. Though the dynamic of Indonesian decentralization was also highly influenced by International Donor agendas on good governance (Widianingsih 2006; Widianingsih \& Morrell 2007; Widianingsih 2015 Widianingsih, McLaren, McIntyre-Mills 2017). In water management in In many International actively involv program different lo

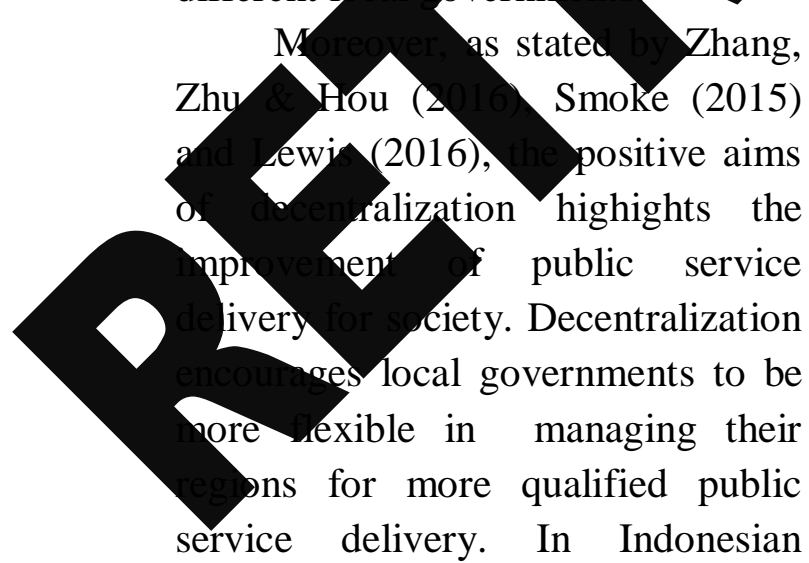
context, some studies revealed that instead of making faster improvement of public services, reverse impact occured in local public service deliveries. This could be related to the readiness of changing local government system, limited participation of society, and limitless of political intervention.

As this paper focuses on discussies the challenges of wastewater governance of ndung Municipality in the Post tuto Indonesia. Research (Horn, 2016) stated the $70 \%$ out Indonesia un erfory to $\mathrm{k}$ manasem an political dy 2 s. I rmore, the World WSP Jater ano jation Program found the last two decades, there are a gradual increase of water sery in rural and urban areas. partly related to "a wellfunctioning service delivery pathway" with a stronger policy and istitutional frameworks. However, the evaluation report also revealed the unsupported financial system often hinder the succesful implementation of the program (World Bank Water and Sanitation Program, 2015).

In the case of wastewater governance in Bandung Municipaliy Water Utility Service (Perusahaan Daerah Air Minum, PDAM), the Post-Suharto Indonesia decentralization often challenged by the fragile administrative system and inefficient resources uses and allocations. According to local regulation no. 15/2009, the PDAM has an authority to manage 
Vol.04, No.02, Oktober 2018

Doi: $10.24198 /$ cosmogov.v2i2.xxxxx

wastewater affairs in Bandung municipality. By comparing two different funding sources, the research found different results. In the case of Wastewater infrastructure development, the local funded program performance is less efficient compared the one using external support. It concludes that local autonomy and democracy should be accompanied by governance and administrative reform for better performance.

\section{RESULT}

Implementation decentralization in Indonesia has been the focus of considerable government attention. Hence, law $32 / 2004$ appears to clarify law $22 / 1999$ for local gove Under law 32/2004, government is levels: provincial municipaly Decentr centr prover powers of local powers of local This per defines the local democy as the implementation of ecentudization. Concept of ntralization is about distribution of power and authority from the highest to lowest government level (Smith, 1985, p. 1). Decentralization involves different level of government combining with different functions. One of an example is
Indonesia: central government doesn't give all authorities for local government according to law $32 / 2004$. It proves that every level of government has its functions. Even though a country implements decentralization governmen central government still centralized som of authorities.

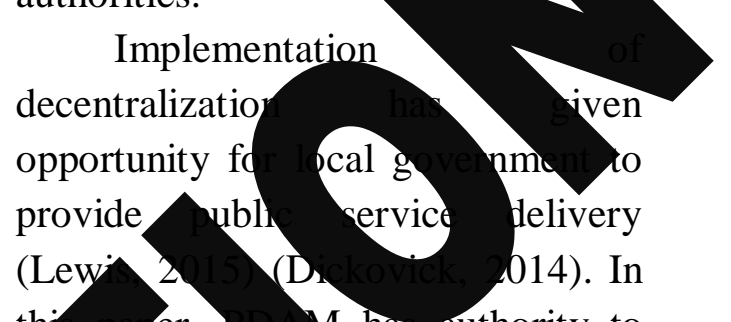
they (Dick o14). In wasterater service in bandu, municiparity. PDAM has to manage frowater affairs from planing to evaluation process. Wa te ater management is one of critical issues in Indonesia. In 2010, central government decentralized a sanitation development program named as Percepatan Pembangunan Sanitasi Permukiman (PPSP) to some big cities in Indonesia like Bandung municipality. It focuses to address some sanitation problems including wastewater management.

In Bandung municipality, citizens and government are concerned about clear water management. Both focus on how to get clean water and avoid water scarcity. However, wastewater needs to be managed, especially because in Bandung area the coverage of centralized wastewater treatment is still limited (Rahmasary, 2017). Hence, local government has to 
Vol.04, No.02, Oktober 2018

Doi: $10.24198 / \operatorname{cosmogov} . v 2 \mathrm{i} 2 . x x x x x$

provide an efficient wastewater management project for citizens.

Before PPSP implementation, wastewater service coverage in Bandung municipality was 29\% (Table 1). It means that PDAM hasn't provided wastewater service successfully. More than $70 \%$ of population in Bandung municipality didn't get wastewater service. By implementing PPSP, the provision of wastewater service has to increase up to $70 \%$ in 2015 . Table 1 presents that PDAM couldn't achieve $70 \%$ of wastewater service coverage in 2015. Furthermore, according to Indonesian National Medium Term Development Plan 2015-2019 wastewater service coverage has t be increased up to $100 \%$ in 2019 .

Table 1

Bandung Wastewater Ser

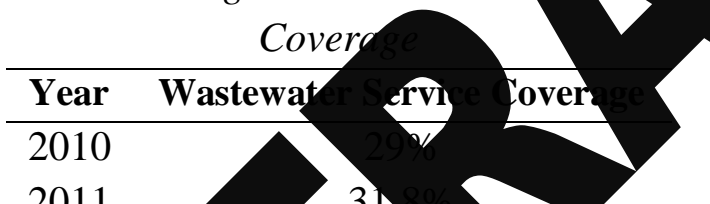

2011

2012

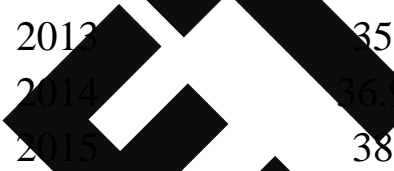

0

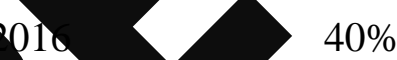

urce. en finding (2017)

2011, Australian Agency for

Development

(AusAID) supported Indonesian sanitation development through Australia-Indonesia Infrastructure Grants for Sanitation (sAIIG) program. It provided grants for local government to increase wastewater service coverage. Although it was for local development, central government had some authorities in this program. Directorate General of Cipta Karya and Ministry of Finance were representatives of central government in this program ure 1.). It shows how cent tries to shift from rowin government concept, cent involved de gover ring ing directry enhardt, $20>14$ this case, it was by ing implementation of project.

Responding sAIIG program, PD proposed a development plan al for installing wastewater pipes in Bandung municipality. Based on Table 1, PDAM needed more efforts for providing wastewater service in 2010. PDAM offered 1.500 pipes installation for low-income communities and required 7.5 billion rupiahs for installing wastewater pipes. As the acceptance of proposal, PDAM had to install 1.500 wastewater pipes for low-income communities in 2011. The program was running successfully and increasing $2.8 \%$ of wastewater service coverage in Bandung municipality. However, the target of wastewater service coverage hadn't been achieved yet in 2011. 
Vol.04, No.02, Oktober 2018

Doi: 10.24198/cosmogov.v2i2.xxxxx

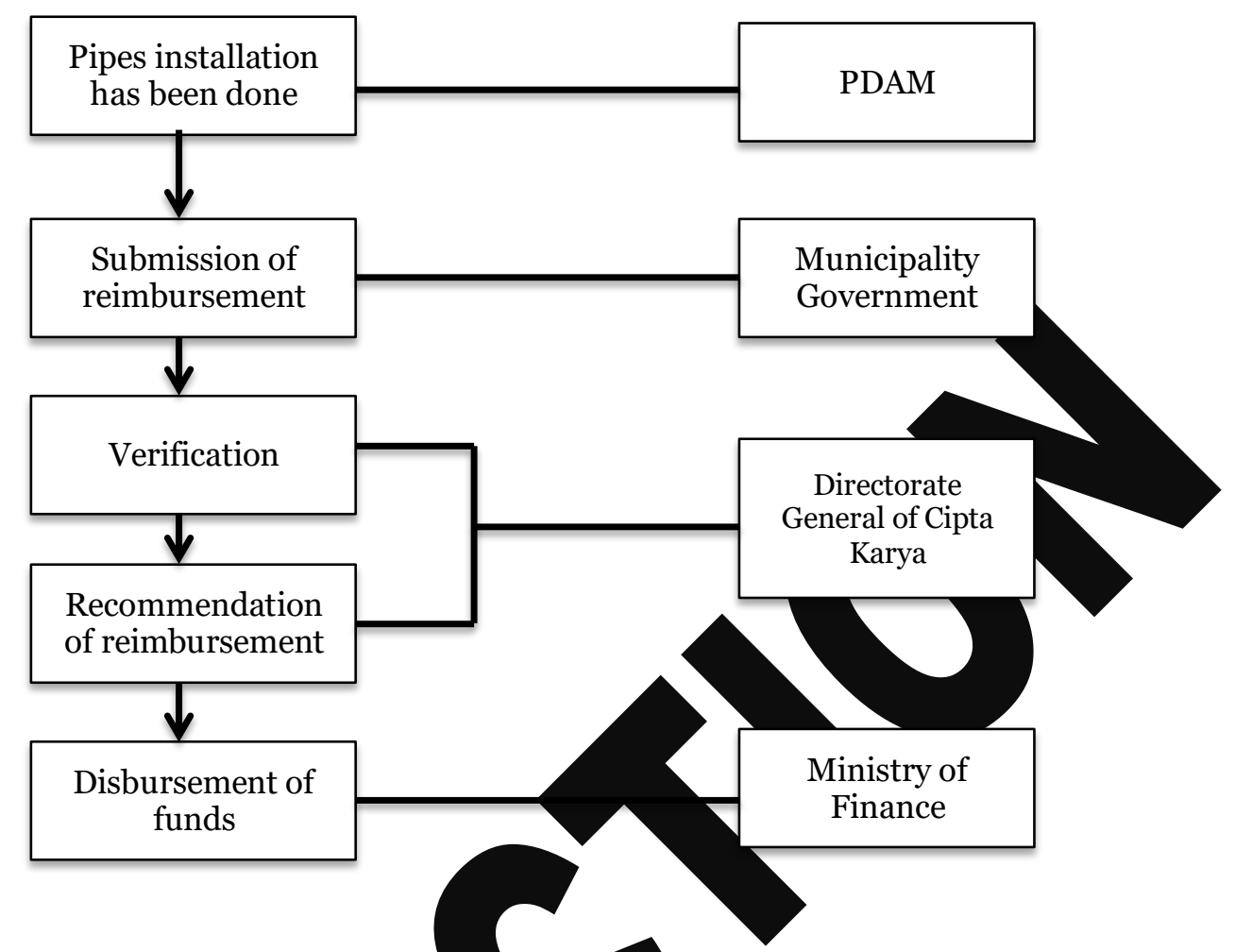

Figure 1. Authority of Indonesian government in $S A I I G$ progrd

Source: (Directorate Genc

Cipta Karya, 2012)

In 2012

wastewater serce co ge wibut any

Enh ment of isAID. age from 20 ole 2) It was because was because DA r du cudget allocation for tallin ewater pipes. In 2011, 9]ucated 7.5 billion rupiahs easing wastewater service rage up to $2.8 \%$. Then in 2012 , PDAM allocated 4 billion rupiahs for increasing wastewater service coverage up to $1.2 \%$ (Table 2 ).
$T a b$ Allocation for Wastewater Service Project

\begin{tabular}{lcc}
\hline Year & $\begin{array}{c}\text { Enhancement } \\
\text { Wastewater } \\
\text { Service }\end{array}$ & $\begin{array}{c}\text { Budget } \\
\text { (billion } \\
\text { rupiahs) }\end{array}$ \\
\hline $2010-2011$ & $2.8 \%$ & 7.5 \\
$2011-2012$ & $1.2 \%$ & 4 \\
$2012-2013$ & $2 \%$ & 11 \\
$2013-2014$ & $1.9 \%$ & 13 \\
\hline Source: & PDAM annual & reports
\end{tabular}
(2014)

Table 2 shows that AusAID wastewater management project is more efficient than local government project. For increasing wastewater coverage up to $1.2 \%$, PDAM should need 3.2 billion rupiahs. Instead of that, PDAM allocated 4 billion rupiahs in 2011-2012. Inefficiency also happened in 2012-2013 and 
Vol.04, No.02, Oktober 2018

Doi: $10.24198 /$ cosmogov.v2i2.xxxxx

2013-2014 project. In 2012-2013, PDAM allocated 11 billion rupiahs for increasing $2 \%$ wastewater service (Table 2). Although in 2010-2011, PDAM allocated only 7.5 billion rupiahs to increase $2.8 \%$ of wastewater service coverage for AusAID wastewater management project. Emergence of inefficiency project is shown by comparing AusAID wastewater management project and local government project. Through AusAID project, PDAM increased wastewater service coverage efficiently.

This project reveals the failure of decentralization implementation obviously. Implementation decentralization would lead greater efficiency in public delivery (Snyder, Ludi, Tucker, Zeleke, \& Duncan, However, it didn wastewater Bandung local goy influene Bas sement proje proje re the same. aference of those projects

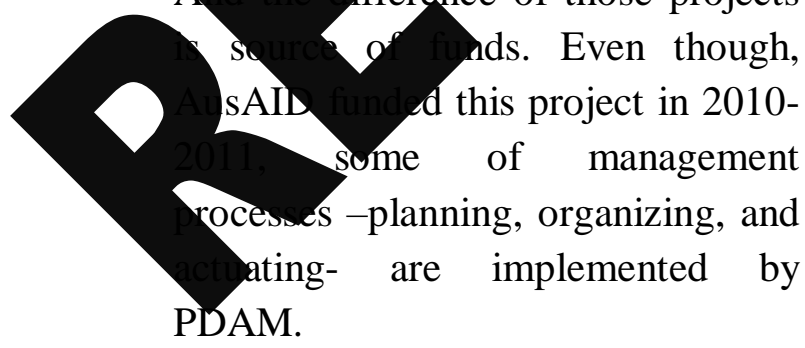

\section{DISCUSSION}

Implementation of AusAID wastewater management project was according to PDAM development proposal for increasing wastewater service in Bandung municipality. It means that PDAM conducted all of wastewater development plans including budget allocation for this project. Basically, AusAID had two roles as donor and supervis in this project. Even though AusAID furded wastewater manage nro. local government still ha for managing AusAID proj local go unm perfo $d$ in a good nerm nce Bun sowed an in ficintly prect within local rent pros

emergence of local governme xibility could not be resiond in decentralization goy ment. Decentralization gives pation opportunities for responding local needs to local government (Grindle, 2007, p. 167). Hence, it might increase the efficiency of government programs. In this case, it leads to an efficient wastewater management program within AusAID projects not local government project. The emergence of AusAID produces a better performance of local government flexibility in this project.

There are some significant differences of these projects. Those are goal setting, controlling, and funding systems. In AusAID project, the goal is very specific -PDAM had to install 1.500 wastewater pipes in 2010-2011. Comparing with local government project, it was determined for five years - 
Vol.04, No.02, Oktober 2018

Doi: $10.24198 /$ cosmogov.v2i2.xxxxx

wastewater service coverage has to increase up to $70 \%$ in 2015 . There was no specific target to be achieved per year. However, an organization needs to set a specific goal because it leads to better performance (Walker \& Andrews, 2013). It also makes organization performance assessment clearer.

In local government project, PDAM did not set a specific goal because wastewater management is not a priority to be achieved. According to local regulation 15/2009, PDAM has authorities for wastewater and water management in Bandung municipality. And somehow, water management is PDAM priority. For these severa years, PDAM concerns to increase water service delivery. BC that, budget allocation for ato management is $\mathrm{m}$ hore wastewater also initiates or increasing war servico detincry. And the vecific 2 to be ach aralization nentation in to improve public eliy So that, Indonesia sector reform. It ds some key points, such as aa suting, success determination performance measurement (Brinkerhoff \& Brinkerhoff, 2015). By setting a specific goal, success determination and performance measurement could be determined easier. A clear performance measurement helps organization to observe some related factors in program implementation (Poister, 2003, p. xvi). Furthermore, organization could identify strength and weakness of program implementation (Wagner III \& Hollenbeck, 2010, p. So, organization could prepare sce challenges in future past experience.

\section{Basically} organization organiza
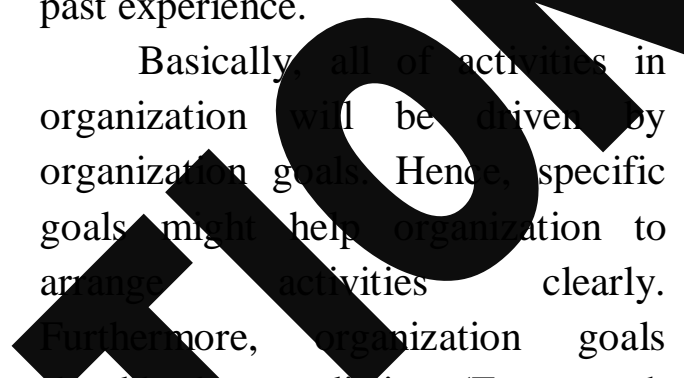
n (n) $\gamma$ snould realistic (Farazmand, 2001, p. - Organizational goal is the first step to determine org ational change. Hence, public zation that avoids to sett specific goals will not implement good governance successfully.

In AusAID project, the funding system is reimbursement. So that, PDAM had to finish installing wastewater pipes before submission the reimbursement (Figure 1). From this project, PDAM had installed 1.500 wastewater pipes in 20102011. PDAM obviously achieved project target successfully. Reimbursement funding system might influence implementation of wastewater management project. Because PDAM only would be paid for wastewater pipes that had been installed. It means that if PDAM installs 1.300 wastewater pipes, then PDAM will be paid only for installing 1.300 wastewater pipes. 
Vol.04, No.02, Oktober 2018

Doi: $10.24198 /$ cosmogov.v2i2.xxxxx

Furthermore, AusAID project funding system was based on PDAM achievement.

Figure 1 also shows the reimbursement process of AusAID project. Even though, wastewater pipes installed, Directorate General of Cipta Karya would verify it before give recommendation of reimbursement to ministry of finance. In other words, AusAID project has some steps to be trough before the disbursement of funds. Other than that, considering development plan proposal and its implementation was also implemented in AusAID project. Local government was forced to be more accountable within this project And basically, good governance requires local accountability to improve service delivery (Ao/ 5).

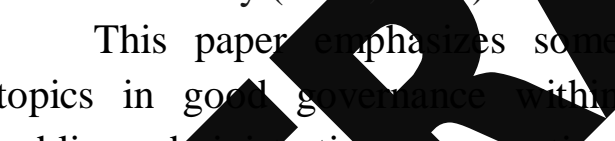
public Good
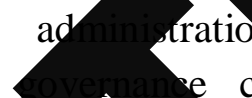

arspounce. topi such accountability, rarepy, entect eness, and e (Gisselquist \& Resnick, 014. Ac roability of local vernn would lead to better erformanoe. It is also a focus of Donosusince the late 1990 (Repucci, y). Hence, within AusAID project forced local government to be more accountable. Accountability comes to be a critical issue in government reform that has to be considered. It could be created by implementation of reward and punishment system in public organization (Hong, 2016). Which is based on employee performance.

In local government project, the funding system is very different. AusAID project offered reimbursement system th was based on the achievement. In of considering achiev government offered project at obviously the posity Au D projea finished in alligs in vater pipes, local nent furde project even when poject had not done yet. In this cas it influences local goverpment performance. Since the vas no specific goal to be ed, then local government funded project at the beginning, these made it further from good governance.

Reimbursement system might be the corruption control in a project. So that, negative behaviors from bureaucrats could be handled. Fighting corruption is one of aims of foreign aid (Frot, 2014). Hence, AusAID implemented reimbursement system for wastewater project. Furthermore, donor policies might influence the effectiveness of aid project (Dalgaard, 2008). Even in this case, AusAID project run effectively, PDAM could achieve the target for installing 1.500 wastewater pipes in Bandung municipality. It proves that AusAID policies -reimbursement 
Vol.04, No.02, Oktober 2018

Doi: $10.24198 /$ cosmogov.v2i2.xxxxx

system and goal setting- led to an effective wastewater project.

Other than that, this paper also proves that reimbursement funding system made wastewater project run efficiently. Efficiency is also an important topic in good governance. The aim of decentralization implementation is making public service delivery more efficient (Saito, 2008, p. 32). Unfortunately, this project revealed that local government project run inefficiently. Table 2 proves that budget allocation of AusAID project is more efficient.

Basically, allocating resources has to be based on results or achievements of projects (Poister 2003, p. 11). In this case, PDAM ha to allocate resources for increasing wastewater service delivery but PDAM does not have a target to be Hence, PDAM resources for spec targe aing reso 0
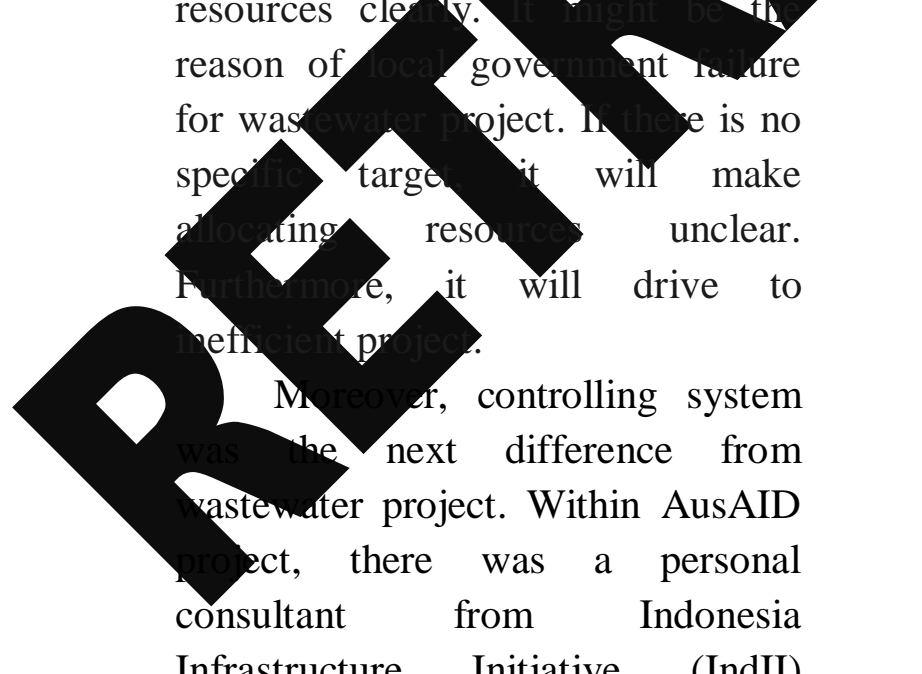

Infrastructure Initiative (IndII) Facility. It had authority to control all of activities during AusAID wastewater project. It ensured AusAID project running effectively.
Controlling system is also an important part to create good governance (Mcnabb, 2009, p. 193). The degree of control might influence all of activities in organization (Osborne \& Brown, 2005, p. 84). Hence, within s AID project, controlling system to be critical topic.

\section{Control of institutio}

to avoid corr ption pbavilit in project. Cont ng in AusAID roje vas en ive. At least and to efficently. Even bureat of local government. Without ssistance of personal con- dant during the project, effi ie cy and effectiveness of water project might not be created. Immature bureaucrat is one of several reasons for decentralization failure in Indonesia. In public service delivery reform, immature bureaucrat is a challenge that could not be avoided. And controlling system might help organization to face that challenge.

In contrast for local government project, there was no personal consultant. The controlling system was authority of local legislature (DPRD) Bandung. It is typical of government organization to be controlled by legislative (Mcnabb, 2009, p. 94). All of PDAM activities including budget allocation are according to DPRD regulation. Hence, PDAM needs DPRD approval for water and wastewater 
Vol.04, No.02, Oktober 2018

Doi: 10.24198/cosmogov.v2i2.xxxxx

development plan in Bandung municipality. For local government project, PDAM has flexibility to manage wastewater and water development plan in Bandung municipality. However, the final decision is still involving DPRD decision.

Controlling model for local government project is making annual reports to DPRD. In this case, that model did not drive to effective and efficient project successfully. Models of AusAID project and local government project are literally different. As mentioned before, the funding system AusAID project was reimbursement system. It could be one of controlling model that had been chosen by AusAID to control a project. Within AusAID controlling system was big annual reports. central General of govern verifying

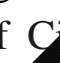
local
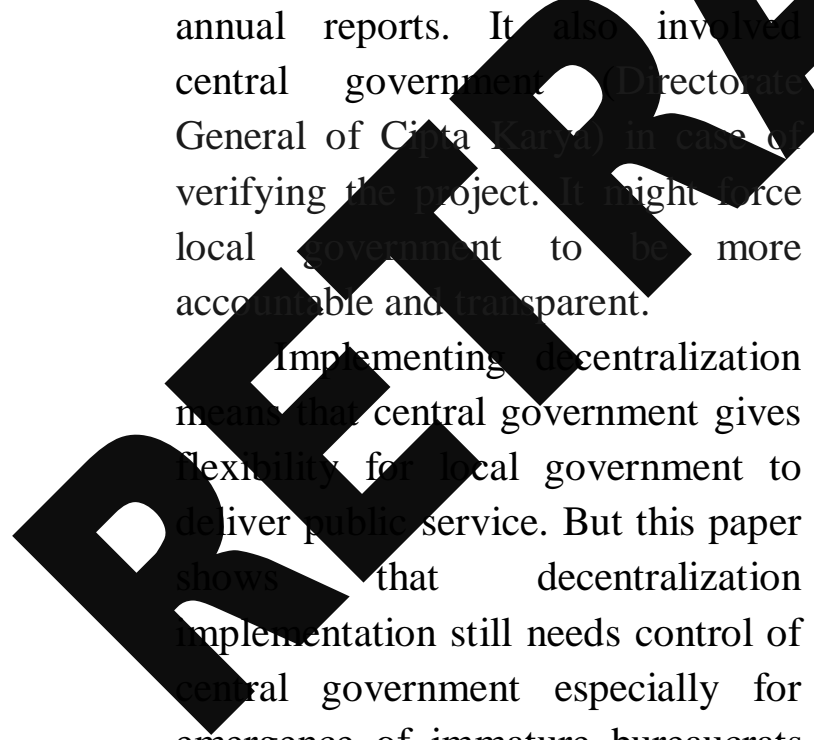
emergence of immature bureaucrats case. Flexibility is given for making public service delivery efficiently. But for this case, flexibility did not work as well as the expectation. This paper reveals that instead of making project more efficient, flexibility drove to inefficient wastewater project. Even though, Indonesia implements decentralization government, central government control of local government activities is still needed.

Controlling determine a transpa government (Lindert 2010, p. 21). provide 2010, over system vill ancy

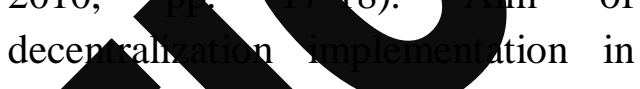
In 1 a viving to greater bility and transparency of local anment. In this case, creating things require a suprative controlling system. Con roling system aims to monitor nake correction of project activities (Wagner III \& Hollenbeck, 2010, p. 16). Comparing AusAID project with local government project shows that there is an immature bureaucrat in Bandung municipality because of the fragile administrative. Hence, choosing best controlling system is needed.

\section{CONCLUSSION \\ ANDRECOMMEDATION}

Basically, the aim of all government activities is improving public service delivery and creating good governance. This paper reveals that creating good governance in local government might face some challenges such as immature bureaucrats because of the fragile administrative. Furthermore, it 
Vol.04, No.02, Oktober 2018

Doi: $10.24198 /$ cosmogov.v2i2.xxxxx

identifies some factor for avoiding the fragile administrative by learning from wastewater project in Bandung municipality:

1. Setting specific goals to be achieved, it will help to determine performance measurement and budget allocation clearly.

2. Funding system based on result, it will increase accountability of local government. It also could be corruption control within a project.

3. Tight controlling system, it will lead to transparency government. Involvement central government is also needed.

In this case,

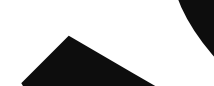

those
Adminitration and Development, 206-218.

Brinkerhoff, D. W., \& Brinkerhoff, J. W. (2015). Public Sector Management Reform in Developing Countries: Perspectives Beyond NPM Orthodoxy Public Administration and Develo 222-237.

Dalgaard, C. J. (2 policy rules ournal of Ed mic Control The New Public mic fred ness. am \& New York. Y.E.Sharpe . Foreign and Decentralization: Lipintion on Impact in Autonomy and Responsiveness. Public istration and Development, 194-206.

Directorate General of Cipta Karya . (2012, 6 7). Pelaksanaan Program Hibah Air Limbah. Workshop FORKALIM, Balikpapan, East Kalimantan, Indonesia.

Erb, M., Priyambudi, S., \& Faucher, C. (2005). Regionalism in Post-Suharto Indonesia. London and New York: RoutledgeCurzon.

Farazmand, A. (2001). Handbook of Comparative and Development Public Administration. New York: Marcel Dekker, Inc.

Frot, E. (2014). Aid Effectiveness in Times of Political Change: Lessons from the PostCommunist Transition. World Development , 127-138. 
Vol.04, No.02, Oktober 2018

Doi: $10.24198 /$ cosmogov.v2i2.xxxxx

Gisselquist, R. M., \& Resnick, D. (2014). Aiding Government Effectiveness in Developing Countries. Publis Administration and Development, 141-148.

Grindle, M. S. (2007). Going Local Decentralization, Democratization, and the Promise of Good Governance. New Jersey: Princeton University Press.

Hadiz, V. R. (2010). Localising power in post-authoritarian Indonesia. Stanford: Stanford University Press.

Osborne, S. P., \& Brown, K. (2005). Managing Change and Innovation in Public Service 5 Organizations. New York: Taylor \& Francis Group.

Hong, S. (2016). What Are the Areas of Competence for Ce Local Governments? Accoun Mechanisms Governance. Administrat , 1-15.

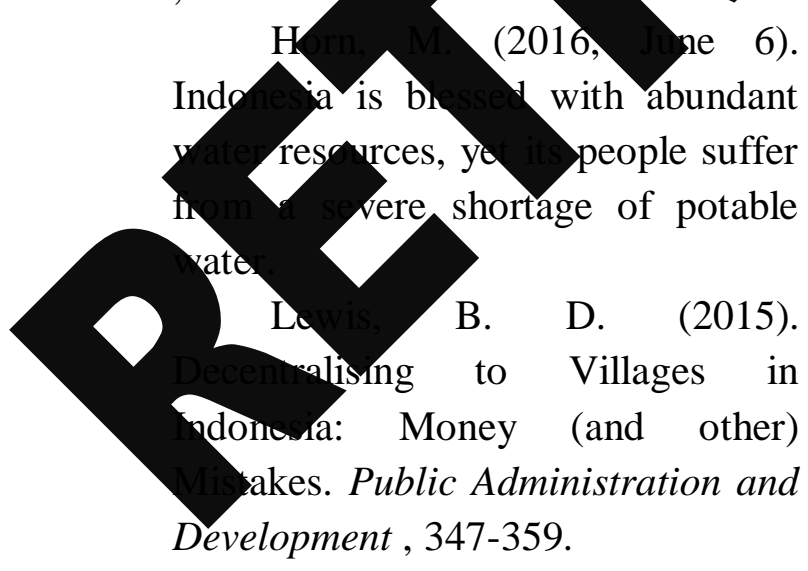

Lindert, P. V., \& Verkoren, O. (2010). Decentralized Development in Latin America. Heidelberg: Springer Dordrecht.
Mcnabb, D. E. (2009). The New Face of Government. Boca Raton: Taylor \& Francis Group.

Osborne, S. P., \& Brown, K. (2005). Managing Change and Innovation in Public Service 5 Organizations. New York: 7 vlor \& Francis Group.

Perusahaan Dae And

Tirtawening Kota Band

Rekapitulasi

Pemasaran A

Bandung PDA $m b a$ virtawe and reksi 3.

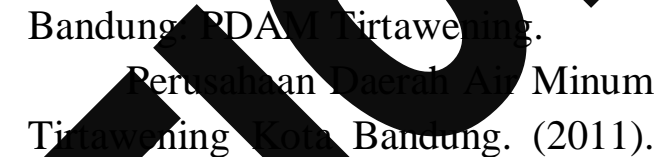
Ker Jan Anggaran erubo Perusanaan Daerah Air Minum \vening Kota Bandung Takn 20M. Bandung: PDAM Tiry ning. Perusahaan Daerah Air Minum Tirtawening Kota Bandung. (2012). Rencana Kerja dan Anggaran Perubahan Perusahaan Daerah Air Minum Tirtawening Kota Bandung Tahun 2012. Bandung: PDAM Tirtawening.

Perusahaan Daerah Air Minum Tirtawening Kota Bandung. (2013). Rencana Kerja dan Anggaran Perubahan Perusahaan Daerah Air Minum Tirtawening Kota Bandung Tahun 2013. Bandung: PDAM Tirtawening.

Poister, T. H. (2003). Measuring Performance in Public and Nonprofit Organizations. San Francisco: Jossey-Bass.

Rahmasary, A. N. (2017). Management Comparison Of WaterRelated Challenges In Asian Cities: 
Vol.04, No.02, Oktober 2018

Doi: $10.24198 /$ cosmogov.v2i2.xxxxx

The Study Case of Water Governance Capacity In Bandung. Utrecht: Universiteit Utrecht.

Repucci, S. (2014). Designing Effective Civil Service Reform Lessons from Past Experience. Public Administration and Development, 207-218.

Saito, F. (2008). Foundations for Local Governance. Heidelberg: Physica-Verlag.

Smith, B. C. (1985). Decentralization The Territorial Dimension of the State. London: George Allen \& Unwin.

Smoke, P. (2015). Managing Public Sector Decentralization in Developing Countries: Moving Beyond Conventional Recipes Public Administration Development , 250-262.

Snyder, K. Cullen, B., Tucker. \& Duncan, A. and Perforp Planning Ethiopi De nent,

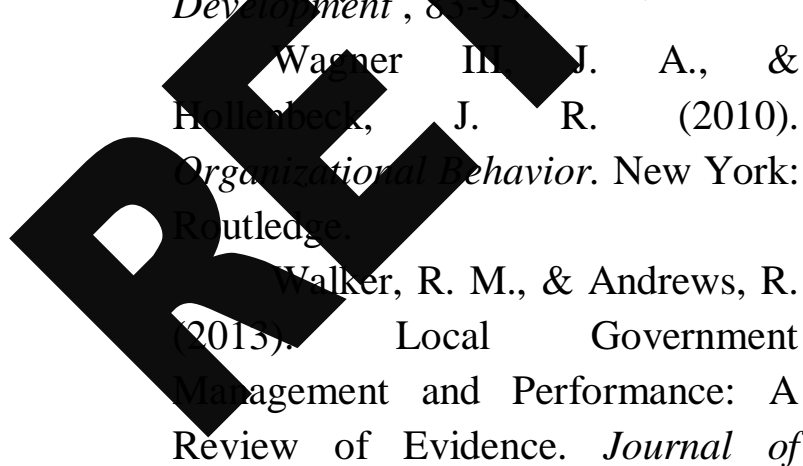
Public Administration Research and Theory, 101-133.

Widianingsih, I. (2006). Decentralization and Participation in Indonesia: Moving towards more
Participatory

Planning?

Sosiohumaniora, 39.

Widianingsih, I. (2015). International Technical Assistance for Local Governance Reform in the Post-Suharto Indonesia: Sustaining Aid Effectiveness? . In Inte Nitional Conference on Public Admin trion (ICPA 11th) Chengdu: UESTC. Widianin (2007). Parti

\section{tory}

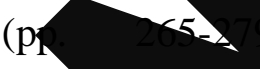
Indonesis see in a ng path to demorad Pic stuctes -15 . dian ${ }^{4}, \mathrm{I}$, , vicLarent, H., Yills, M. (2017). participatory
planning the Anthropocene in Indensia, with a case example of the Ber Ig $k$ Dese, Lombok, Indonesia. M. Mills, \& Y. C. Nantes, Contemporary System Thinking: Balancing Individualism \& Collectivism to Support Social and Environmental Justice. London: Springer.

World Bank Water and Sanitation Program. (2015, May). Retrieved May 20, 2017, from www.wsp.org: https://www.wsp.org/sites/wsp.org/fi les/publications/WSP-IndonesiaWSS-Turning-Finance-into-Servicefor-the-Future.pdf

Zhang, P., Zhu, C., \& Hou, Y. (2016). Fiscal Decentralization, Flat Administrative Structure, and Local Government Size: Evidence and Lessons From China. Public Administration and Development, 198-214. 
Vol.04, No.02, Oktober 2018

Doi: $10.24198 /$ cosmogov.v2i2.xxxxx

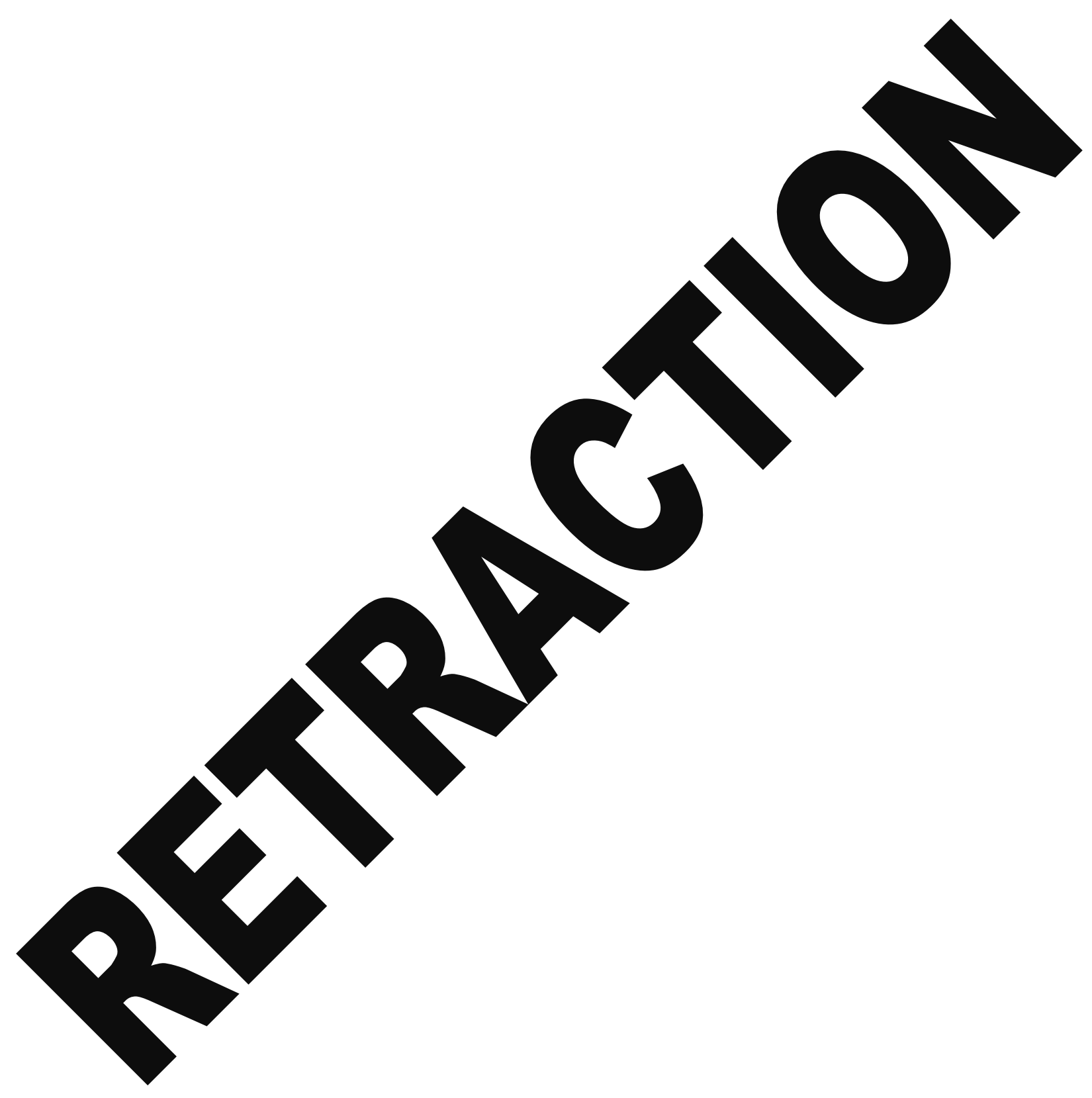

